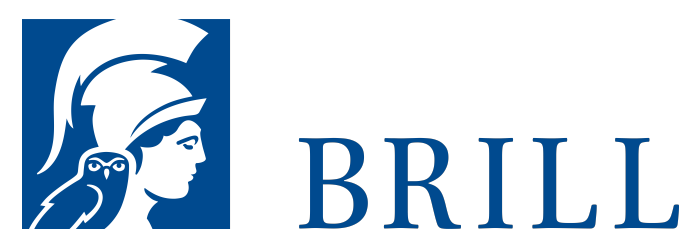

\title{
Diachronic Syntax: The Kartvelian Case
}

Author: Alice C. Harris

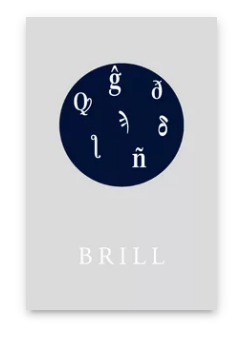

Language:

English

Subjects:

Morphology \&

Syntax,

Languages and

Linguistics,

Historical and

Comparative

Linguistics \&

Linguistic

Typology,

Languages and

Linguistics,

Semantics,

Languages and

Linguistics

Publisher: Brill

Series:

Syntax and

Semantics,

Volume: 18

E-Book (PDF)

Released online:

13 Jan 2020

ISBN: 978-90-

o4-37314-3

List price

USD $\$ 119.00$

Hardback

Publication date:

o1 Jan 1985 
For more information see brill.com

ISBN: $978-90-$

04-365०8-7

List price

USD $\$ 112.00$

Order information: Order online at brill.com

+44 330333 0049 | customerservices@brill.com

Submission information: brill.com/authors

Titles published by Brill | Fink, Brill | mentis or Brill | Schöningh:

+49(o)71 5413279216 | brill@brocom.de 